ENTREPRENEURSHIP AND SUSTAINABILITY ISSUES

ISSN 2345-0282 (online) http://jssidoi.org/jesi/ 2020 Volume 8 Number 2 (December) http://doi.org/10.9770/jesi.2020.8.2(1)

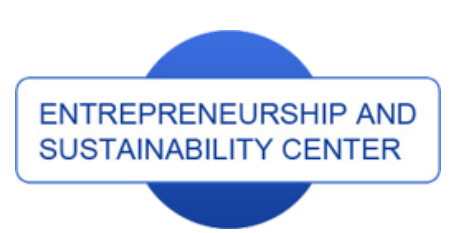

Publisher

http://jssidoi.org/esc/home enterprise

europe

network

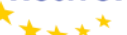

Business Support on Your Doorstep

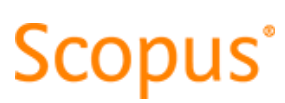

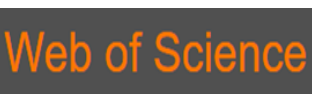

1 Clarivate

Analytics

\title{
STRATEGIC REACTIONS TO INFORMATION CONTENT OF DIVIDEND CHANGE: APPLYING BCG GROWTH SHARE MATRIX WHEN SIGNALLING HYPOTHESIS IDENTIFIED
}

\section{Alireza Aghaee Shahrbabaki ${ }^{1}$, Saeed Sakkaki ${ }^{2}$, Peyman Parsa ${ }^{3}$, Mohammad Saeed Heidary ${ }^{4}$, Vahid Yousefi Pour ${ }^{5}$}

\author{
${ }^{1}$ Bocconi University, Department of Finance, via Roentgen 1, 20136 Milan and SDA Bocconi School of Management, \\ Milan, Italy \\ ${ }^{2,5}$ Graduate School of Management and Economics, Sharif University of Technology, Azadi st. P.O.Box 1458889694, \\ Tehran, Iran \\ ${ }^{3}$ Department of Industrial Enginerring, K.N. Toosi University of Technology, No. 19, Pardis Street, Molla Sadra Ave., Vanak \\ Sq., P.O. Box 1999143344, Tehran, Iran \\ ${ }^{4}$ Department of finance, Faculty of Management and Accounting, Allameh Tabataba'i University, West End Hemmat Highway, \\ Dehkadeh-ye-Olympic, 1489684511, Tehran, Iran
}

E-mail: ${ }^{1 *}$ alireza.aghaee@phd.unibocconi.it (Corresponding author)

Received 18 March 2020; accepted 20 September 2020; published 30 December 2020

\begin{abstract}
The signaling hypothesis has been vastly under investigation for many years. There are two attitudes towards this phenomenon; some believe that firms increase (decrease) their dividend to signal about the future increases in earnings due to asymmetric information that managers have. Adversely, others believe that firms usually increase their dividends when they do not have further lucrative projects with positive net present values. Although there is a lot of empirical testing about this hypothesis that has been placed, there is no investigation about agency costs and cheating potential signaling hypothesis can provide for managers to cheat shareowners and market if it happens in the stock market. Through this article, we will test the signaling hypothesis for the firms listed in Tehran Stock Exchange, a rather volatile emerging market. We concluded that while dividend increases have no significant information content about future earnings, dividend decreases have meaningful information content about decreasing earning in the future. We use different scenarios that managers can react if the signaling hypothesis occurs and analyze the agency cost these scenarios bear on shareowners.
\end{abstract}

Keywords: dividend policy; signaling theory; Agency cost; BCG matrix

Reference to this paper should be made as follows: Aghaee, S.A., Sakkaki, S., Parsa, P., Heidary, M.S., Yosefi Pour, V. (2020). Strategic reactions to information content of dividend change: applying BCG growth share matrix when signalling hypothesis identified. Entrepreneurship and Sustainability Issues, 8(2), 10-32. http://doi.org/10.9770/jesi.2020.8.2(1)

JEL Classifications: G1 


\section{ENTREPRENEURSHIP AND SUSTAINABILITY ISSUES}

ISSN 2345-0282 (online) http://jssidoi.org/jesi/ 2020 Volume 8 Number 2 (December) http://doi.org/10.9770/jesi.2020.8.2(1)

\section{Introduction}

Dividend signaling theory states that managers use dividend changes to signal asymmetric information about the future profitability of the company, it seems that a study of changes in dividends and future profitability in the corporate finance field is a subject worth to be considered and discussed (Baker 2017). Probing the managers' perspective to dividend-paying, their purpose of it, and the issues they consider in dividend decisions, has long been a heated debate between scholars in the financial literature. For instance Smith (2017) analyses it in earning management context and James (2015) discover whether signaling theory and dividend paying increase social responsibility. In every financial market, whether in developed countries or emerging ones, why, how, and to what extent capital returns to investors is of great importance. On the other hand, the ability to transfer surplus values to productive investment opportunities is one of the crucial factors of economic growth. Although there are different works about testing signling theory, but research in developing markets, is not get to a conclusive stage (Abdulla 2016, Aivazian 2003).

In literature, three major methods are used to test this particular category of assumptions. The first method is to examine whether and how dividend changes can predict changes in future stock price. The second method tests whether and how dividend changes can predict the future accounting profitability of the firms. Specifically, with these two methods, if the assumptions are statistically accepted, it is claimed that companies use dividend changes as a harbinger of their future profitability. The third method, which is much less used and presumably has less power to corroborate or reject the hypothesis, is interviewing with corporate executives and financial officers and asking them about this approach to use dividend changes in order to signal about future earnings (Brav 2005, Baker 2002, Baker 2017).

One of the issues related to the signaling theory is to examine the relationship between dividend changes and future profitability changes. In fact, since managers' expectations of future profitability can be effective in firms' dividend-paying decisions, dividend changes, due to changes in the company's capital structure, can affect future profitability. Therefore, a robust and detailed econometric method is needed to investigate this endogenous relationship between dividend changes and profitability changes for a more accurate test of signaling theory. The first motive for this study is to investigate this endogenous relationship between dividend changes and future profitability changes, and this is done using a simultaneous equation method to control other effective variables. Another important issue is that this study is testing the theory in the emerging market of Iran. Literature has shown that in developing countries, it is necessary to think about certain considerations in the application of conventional financial theories. This happens for the higher risk of credit in both firms and countries, the existence of specific rules and laws for each country, the inability in using many common financial instruments (for example no existence of short selling in many countries' security market), the size of the capital market in comparison to the total assets, etc. (Booth, Aivazian, Demirguc-Kunt, Maksimovic (2001), Aivazian, Booth, Cleary (2003)). Here, we used the financial data of firms listed in Tehran Stock Exchange.

So far, many empirical findings of the impact of dividends on earnings have been inconclusive, in the sense that they have not led to a comprehensive conclusion; moreover, most of these studies have focused on developed countries such as the USA and UK. While there are limited researches of these kinds in developing markets, few studies have tried to research on the dividend determinants. Researches such as Adelegan (2003) in Nigeria, Ahmed and Attiya (2009), and Afza and Mirza (2010) in Pakistan, Al-yahyaee et al. (2006) in Oman and Al-Najjar (2009) in Jordan, and Baker et al. (2019) in Sri Lankan have been conducted on the factors affecting the dividend policy.

Other studies have also been carried out particularly to test the signaling hypothesis; other studies have also been carried out particularly to test the signaling hypothesis; again the results of these researches are 


\section{ENTREPRENEURSHIP AND SUSTAINABILITY ISSUES}

ISSN 2345-0282 (online) http://jssidoi.org/jesi/ 2020 Volume 8 Number 2 (December) http://doi.org/10.9770/jesi.2020.8.2(1)

inconsistent with each other; this phenomenon is known as dividend puzzling which implies that there is no general rule for different markets. For example, studies in emerging markets by Lukose and Rao (2010) in India, Berezinets et al. (2018) in India, Chaudhary et al. (2016) in Pakistan, Travlos, Trigeorgis, and Vafeas (2001) in Egypt and Dasilas (2007) in Greek stock market, approved the truthfulness of the signaling hypothesis. Whereas studies by Berezinets et al. (2018) in Russia, Al Quadeh et al. (2015) in Saudi Arabia, Kadıoglu and Öcal (2016) in Turkey, and Lotfi (2018) in the Tunisia stock market are inconsistent with the signaling hypothesis. In Iran, Talaneh (1991), Talaneh and Shemirani (2011), Khoshtinat and Hajian (2008), Ardekani et al. (2010), and Keshavarz et al. (2014) have conducted researches on the dividend policy, but these studies did not test the information content of dividend changes on future earnings.

Our first contribution is testing signaling hypothesis in one of developing countries, Iran. So we examine real data by using the information content of dividend announcements and its changes in the companies that are listed on the Tehran Stock Exchange during the period from 2001 to 2017 in Iran, a developing country. Due to limited access to data as well as incomplete and unstructured data, few studies have been conducted on dividend income in Iran. In this study, data were gathered in a variety of ways such as web page crawling. Finally, we put them in a structured, complete, and accurate manner in files to serve to analyze the research question in a wider domain and with much less error than similar local studies.Another contribution of this study is to take inflation as independent variable explaining some systematic changes in dividends and earnings. Iran, like many other developing countries, has suffered a high inflation rate over the recent decade. Therefore, with the inflation ranging from $14 \%$ to $30 \%$ per year, a hypothetical $20 \%$ increase in dividend may be justified barely by taking the effect of inflation into account. Hence, we considered inflation in our model as a meaningful factor to explain the changes in dividends and earnings. Furthermore, our last contribution is about how managers could react to the signaling potential of a dividend increase and decrease using the BCG growth-share matrix. Henderson (1979) developed the BCG matrix for analyzing various firms in corporate business portfolio. In current years, there is a new stream of research on how to apply the BCG matrix in different management issues. Smith (2002) applied the BCG matrix in customer profitability analysis and Widiatama et al. (2018) exploit the growth-share matrix in the market optimization era. We use the BCG growth-share matrix to predict the reaction of managers and different strategies they can take to communicate the stock market when they identified the signaling hypothesis is working.

The rest of this article is organized as follows. The second section reviews the literature for developed and developing markets, which ultimately finds a research gap in literature from the perspective of new source of data in emerging market, Iran. In addition, we find that how to react to the signaling hypothesis is one of the main issues managers would react to dividend strategy selection. The third section describes the data and measurement criteria. The fourth section presents the model used to analyze the data. The fifth section explains the findings of the tests, and the sixth section concludes the paper.

\section{Literature review}

Miller and Modigliani (1961) showed that with the assumption of several conditions, including the absence of taxes, transaction costs, and market imperfections, the market value of a company is entirely independent of its dividend policy. They came to the conclusion that the company's profitability and its investments are only factors affecting the firm's market value and stock price; the result of this study is called the dividend irrelevance hypothesis. Many theories after Miller and Modigliani have tried to show that dividend policy is important in future profitability. The main objection to Miller and Modigliani's theory is that this study is based on an efficient market. In other words, in an imperfect market, dividend policy can have an important effect on market value and future profitability. 


\section{ENTREPRENEURSHIP AND SUSTAINABILITY ISSUES}

ISSN 2345-0282 (online) http://jssidoi.org/jesi/ 2020 Volume 8 Number 2 (December) http://doi.org/10.9770/jesi.2020.8.2(1)

One of the most critical issues in corporate finance is whether and how dividend changes contain information about future profitability. Although dividend signaling theories suggest that dividend increases signal more lucrative prospects (Bhattcharya 1979, Miller \& Rock 1985), many empirical studies have failed to support this argument; for example, studies by Watts (1973), Penman (1983), DeAngelo et al. (1996), Benartzi et al. (1997), Grullon et al. (2002) have observed no or negligible evidence that dividend changes can predict future abnormal earnings. Also, some studies based on surveys and interviews from hundreds of financial managers have shown that managers deny the thought that dividends are used as a signaling device (Brav et al. 2005).

By reviewing literature, even with the assumption that the profitability of a stock is directly and positively correlated with the dividend increase announcements, whether the managers change dividends to signal the prospect of their firms cannot be tested with existing methodologies. In fact, it is possible for an investor to reasonably or unreasonably concludes that managers mostly use dividend changes as signals, which means that investors react positively (negatively) to dividend increases (decreases). While managers may have made this change for some other reasons (like investing for future growth). In addition, Watts (1973), Penman (1983), DeAngelo et al. 1996, Benartzi et al. (1997), Nissim and Ziv (2001), Grullon et al. (2002), Grullon et al. (2005), Brav et al. (2005), Denis and Osobov (2008), and others examined that dividend changes, instead of future stock returns, could predict subsequent accounting earnings. In short, no matter what the motive for dividend change is, what is noteworthy is that distributing dividends by itself may be effective in future profits.

In spite of some previous studies that imply a short span timing of information that dividend changes convey about future income, Increasing dividends by mangers are more likely when they predict a persistent increase in prospect earnings(Ham et al. 2019). According to this paradoxical results in the literature, a study by Kaplan and Perez(2019) shows changes in dividend payout should not be considered as a signaling tool, rather it's more aligned with the standard capital structure models. For example, Managers decide to pay out excess cash to shareholders when there are no investment opportunities.Considering dividend changes, since dividend increases reduce the amount of budget ready for newer investments, companies may lose potential investment opportunities with a positive net present value (NPV), or they will be forced to finance projects at a higher cost, while in either case, it may lead to a reduction in future profits. Also, in the Gordon (1962) model, it has been shown that in a stock portfolio with constant long-term expected returns, high dividend payouts will be offset by low expected earnings growth. In contrast, the agency theory (Jensen 1986; Jensen \& Meckling, 1976) has a different view on dividend payouts. It is explained in the agency theory that due to the possibility of allocating resources to the activities that the managers themselves benefit from the most, increasing dividends can reduce the potential cost related to the agency problems. Meanwhile, corporate dividend payments are more closely monitored by the capital market as firms will visit the capital market with more frequency to meet their financing needs. This continuous monitoring by the capital market will not let managers deviate too much from the main guidelines that investors have in mind.

In an environment with asymmetric information, the dividend announcements and its changes have the potential to transfer internal managers' information to the outside. (Battacharya 1979, John \& Williams 1985, Miller \& Rock 1985). The assumption of signaling has been extensively tested in developed markets, and the results indicate that stock prices have a positive reaction to increase in dividends and negative reactions to decrease in dividends (Aharony et al. 1988, Borde et al. 1999, Eades et al. 1985, Impson 1997). Especially, Lukose, J., and Rao, S. (2010), investigated the theory of signaling in the Indian stock market and showed that dividend initiation has a much greater effect on the share prices than the increase in the dividend payout ratio.

Studies about the dividend signaling hypothesis generally track two different routes. One strategy has been to apply econometric methods to test the theories that are extant in the literature, and another has been to use the surveys filled by corporate executives about what the key dividend policy determinants are. Taking all the 


\section{ENTREPRENEURSHIP AND SUSTAINABILITY ISSUES}

ISSN 2345-0282 (online) http://jssidoi.org/jesi/ 2020 Volume 8 Number 2 (December) http://doi.org/10.9770/jesi.2020.8.2(1)

reviewed theories in mind, one cannot imagine a unique direct impact of dividend changes on future profits, and it should be seen that excavating the data confirms which of the claims in this area.

In short, by excluding dividend change incentives, dividend-paying by itself can be effective in future profitability due to the change in the capital structure. Healy and Palepu (1988) indicated that firms that initiate (omit) dividends realize a significant increase (decrease) in their earnings for at least one year before and the year of dividend change. Similarly, these companies will have a significant increase or decrease in their profitability at least one year after the announcement. Benartzi et al. (1997) used a sample matching approach, in which firms that change dividends are matched with those that do not change dividend based on characteristics such as industry, past performance, and capital structure. Controlling for the earnings pattern and mean reversion, they found that there is no evidence to confirm that unexpected positive change in profitability (earning) occurs after dividend increases.

In contrast to these findings, Nissim and Ziv (2001) claimed that studies such as Benartzi were invalid due to the measurement error in the dependent variable and the problem with the omitted correlated variables. They assumed that current earnings were affected by the first-degree autocorrelation; after considering these problems and the arrangements for them, they found that positive dividend changes are related to changes in earnings for two years after the announcement. Their findings were remarkable because their predecessors who had used regression method reported an adverse result (Penman 1983), or did not find any relationship or found a very weak relationship. Pursuing a similar logic to that of Nissim and Ziv, Harada and Nguyen (2005) argued that the dispersion of the managers' motivation to set dividends might cause dividend change data to act in contrast to the signaling hypothesis.

In order to understand the potential nonlinear relationship between dividends and revenues, many of the former researchers incorporated methods other than ordinary linear regression analysis and reported different results from what Nissim and Ziv found. For example, DeAngelo et al. (1996) examined the dividend policy at times when company revenues were unexpectedly declining and concluded that dividend changes have almost no information about future changes in earnings. Similar results were also reported for the study of Grullon et al. (2002), and authors strongly rejected the claim of dividend signaling. Indeed, consistent findings in different studies with different methods, and often, in contrast to that of Nissim and Ziv, have raised the question of why companies pay dividends.

More recently, Lukose and Rao (2010) examined the stock price reaction to dividend changes and also the relevance of the signaling models in explaining the effects of dividend changes on the valuation of Indian industrial companies. This study analyzed the effect of dividend changes on corporate value, its impact on future profitability, and market response to dividend changes. They noticed the significant wealth effect around dividend changes during the year of changes, and it has been concluded that dividend changes have a significant and meaningful effect on the company's stock value and profitability in the same, but it will not be meaningful in the following years. Particularly, the initiation of dividend paying has a much greater effect than an increase in the payout on increasing the stock prices. Similarly, Liu and Chen (2015) tried to test the dividend signaling hypothesis as to whether managers change dividend profits to signal their expectations of profitability using the simultaneous equation and the data of US companies. Their results showed that managers change dividends to signal equity-scaled rather than asset-scaled earnings prospects. Also, they found evidence that managers change dividends to signal previous earnings changes.

So far, most studies have been concerned with developed markets. In emerging and developing countries we can find a study in Cairo has been carried out by Travlos et al. (2001), which examines the market response to increasing dividends and stock dividends and found that both cases have a significant positive effect on stock returns. In another emerging market, Dasilas (2007) has also seen significant market responses on dividend 


\section{ENTREPRENEURSHIP AND SUSTAINABILITY ISSUES}

ISSN 2345-0282 (online) http://jssidoi.org/jesi/ 2020 Volume 8 Number 2 (December) http://doi.org/10.9770/jesi.2020.8.2(1)

changes in the Athens Stock Exchange. The study, conducted in Greece, examines the market reaction (price effect and volume of trades) to dividend payout announcements by companies. The article states that the structure of the Athens stock market has the following structural differences with other large stock markets. First, dividends in Greece are paid annually rather than quarterly or semi-annually. Second, the Greek corporate laws designate an accurate minimum amount for distribution from the taxed corporate profits. Third, neither tax on dividends nor capital gains is imposed. Fourth, the Greek listed firms are characterized by high ownership concentration where major owners are usually involved in the management and have, therefore, less need for dividend announcements as an information source. Despite all these differences, especially the absence of tax, circumstances seem to be very close to that of Miller and Modigliani dividend irrelevance theory, but this study demonstrates that the dividend announcement has a significant impact on stock prices and future earnings of companies in Greece, which well supports the signaling theory, and highlights the importance of further investigations.Zhao (2016) confirmed the signaling hypothesis by testing the relationship between dividend changes and corporate bond responses. Dividend increase(decrease) leads to a significant increase(decrease) in bond yield. Chaudhary et al. (2016) confirmed the signaling hypothesis by examining the Pakistan stock market reaction to dividend change. Liaqat et al. (2019) have researched the managerial perception about the signaling effect of dividend policy in Pakistan stock exchange as an emerging market. Their study indicates that current earning, past dividends, liquidity, taxation, managerial perspective, investor perception, and share prices have considerable influence on dividend policy. Furthermore, they concluded that the previous year dividend payout has not (or has a weak) effect on the estimation of the current year dividend payout. The other finding of this research is that continuing payout of the dividend could be considered as management performance and convey a positive signal to the market.

Lotfi (2018) shows the Tunisia stock market didn't approve truthfulness of the information content of dividend policy, but when there is a decrease in dividend payout, Lotfi(2018) reports a negative reaction by Tunisia stock market to the announcement of dividend policy.Another study has been conducted in the kingdom of Saudi Arabia stock market (Tadawul) by Al Quadeh et al. (2015). According to their conclusion, there is no significant market reaction to dividend announcements. Thus we could not generalize signaling theory to all kinds of markets. This study enlists the limitations and characteristics of KSA market and emphasizes that limitations of emerging markets have a significant effect on the feasibility of the signaling theory. A study by Kadioğlu and Öcal (2016) in the Turkish stock market reported that there is no significant effect of dividend announcement on stock price, but they found a significant correlation between the increase in stock prices and with the profitability of previous year. A similar study conducted by Tran and Mai (2015) in the Vietnamese stock market; found that different kinds of dividend announcements (increase, decrease, and no change) have a positive effect on stock prices. Berezinets et al. (2018) found a similar result by analysis of Russia stock market during economic growth, in other words, they report a negative reaction to both increase and decrease in dividend policy, but their result for India stock market during economics growth is consistent with signaling theory. The reaction of both Russia and India markets to decrease in dividend are more considerable than to increase in the dividend.

Using regression analysis for causal inference, Tao et al. (2016) investigated the signaling hypothesis in China stock market under a distinctive and special rule called by authors "a semi-mandatory dividend policy", that forces firms to pay a minimum level of dividends to be allowed to do seasoned equity offering (SEO). They found a significant and meaningful positive relationship between an increase in dividend policy and future return for non-SEO firms, but for SEO firms there wasn't such a significant relationship, hence the SEO firms' result is inconsistent with the signaling hypothesis. According to such results, we should emphasize the distinctive behavior of different markets and different categories of stocks in each market. As another example, the effect of a firm's characteristics on signaling behavior is investigated by Gupta and Aggarwal(2018). By analysis of the Indian stock market in three-segment, they found that only mid-cap stocks confirm signaling effect when dividends increase, whereas a change in dividends of small and large-cap stocks didn't affect post-event behavior of the market. Some mix reaction also report in developed and developing market.Literature implies that this is 


\section{ENTREPRENEURSHIP AND SUSTAINABILITY ISSUES}

ISSN 2345-0282 (online) http://jssidoi.org/jesi/ 2020 Volume 8 Number 2 (December) http://doi.org/10.9770/jesi.2020.8.2(1)

not necessary to see similar reactions by the market to dividend change announcement and dividend initiation announcement. For example, by examining stocks in CSRP(the Center for Research in Security Prices) dataset during 1990-2009, Smith and Pennathur (2017) found that dividend increase approves the signaling hypothesis, but dividend initiation effect doesn't support signaling. Rabbani (2017) found a difference between the effect of a dividend increase and a dividend decrease on the market reaction of Bangladesh stock market; whereas dividend decrease supports the signaling hypothesis, dividend increase does not approve it.Nam (2018) researched the role of R\&D on the dividend decision of loss firms; her results support the signaling hypothesis for loss firms with high R\&D activity in South Korea.

Although there are different studies in both developing and developed market but analyzing signaling hypothesis when there is tough economic condition is rarely investigated. A recent study by Khanal and Mishra (2017) focused on the reaction of the market to the dividend announcement in USA markets during the 2006-2012 period which referred to as a "sluggish economic period" by authors. They reported consistency with signaling theory in their findings during this period like previous researches on USA markets, but they underscore the considerable difference in the magnitude of the reactions, about 1.81\% abnormal return in 2006-2012 period compared to 5.9 $\%$ results of previous research on the identical dataset when economy underwent high inflation and tax reform in 1980s.Gafoor et al. (2014) in their research findings indicate that there is a positive relationship between inflation and dividend payment policy. After consideration of the result of this study, along with findings of other similar researches in emerging markets (Baker et al. 2018), it should be emphasized on the importance of inflation impact when dealing with dividend decision issues (Baker and Jabbouri 2016, 2017).In this regard, Basse (2019) by controlling inflation, reinvestigate the dividend decisions of insurance companies of the Euro Stoxx stock market.

To date, a limited investigation about the impact of dividend policy on future profitability has been performed based on Iranian companies. In general, research on the financial market and securities of Iran has suffered too much generalization or other scientific problems due to the lack of access to high quality and structured data. In other words, data limitations are one of the essential factors leading to simplified models and entering analysis errors that directly affect the accuracy, validity, and reliability of the results of previous researches in Iran. In the present paper evaluate the information content of dividend changes in companies listed on the Tehran Stock Exchange during the period from 2001 to 2017. Having accessed, prepared, and aggregated the relevant nonstructured and incomplete data, we are able to analyze the research question in a wider domain, with a more accurate analysis model, and much less error than former local investigations.

In addition, literature shows that there is no research on how managers could react to the signaling potential of dividends and what strategies they would take in different conditions. Furthermore, one can easily found cheating potentials when the signaling hypothesis happens in either direction. The main contribution of this research is to identify those potentials in different scenarios using the BCG matrix and clarify the state of each business when signaling potential happen. This would help shareholders to minimize their risk of having each share when the signaling hypothesis happen.

\section{Data and measurements}

Data gathering was the most significant milestone of this study. The data we needed to perform the tests was as follows (from 2001 to 2017, beginning and end of years are matched with the Persian calendar):

Aggregated data of dividends paid to stockholders;

Earnings per share for all stocks listed on TSE for all or a part of the time interval; Adjusted close price of all stocks listed on TSE for all or a part of the time interval; 
Aggregated data of Book value per share for all stocks in all of the years that firm is listed on TSE within the interval;

Some of the financial ratios of all firms listed on TSE in all or part of the time interval.

Since most of the data above were not neatly extant in any accessible database as a whole, and the others were only accessible only for a part of companies, we finally gathered the required data with a combination of web crawling and programmed robots (Octoparse, developed by Selenium) in conjunction with TSE client software.

Because the data were collected with different methods and from different databases, they needed to be integrated so that the necessary information for analysis would be structurally available. The process of cleaning and preparing collected data was arranged using Python programming to prepare the final data frames and making data ready for analysis.

Table 1 provides a descriptive view of dividend change frequency in TSE. Each column declares the number of records in that year for each of the dividend event types: increase, no change, and decrease. In this table, even a one IRR increase or decrease in dividends is considered as a change. According to Table 1, the dispersion of the dividend changes in the TSE is quite frequent.

\section{Methodology and Analysis}

\subsection{Core concept and main process}

In this research, we follow four steps in analyzing the signaling hypothesis and strategy reactions of a manager. Figure one shows this process for analyzing and predicting management behavior to signaling hypothesis when it is identified in the market. First, we determine whether the signaling hypothesis happens or not. In step two, we calculate the amount of dividend concerning all factors except for signaling hypothesis such as competition and so on. In step three, we find the position of the firm in the BCG growth-share matrix. This helps to understand the status of the firm in the market. In step four, we select the strategy to communicate the market considering the signaling hypothesis.

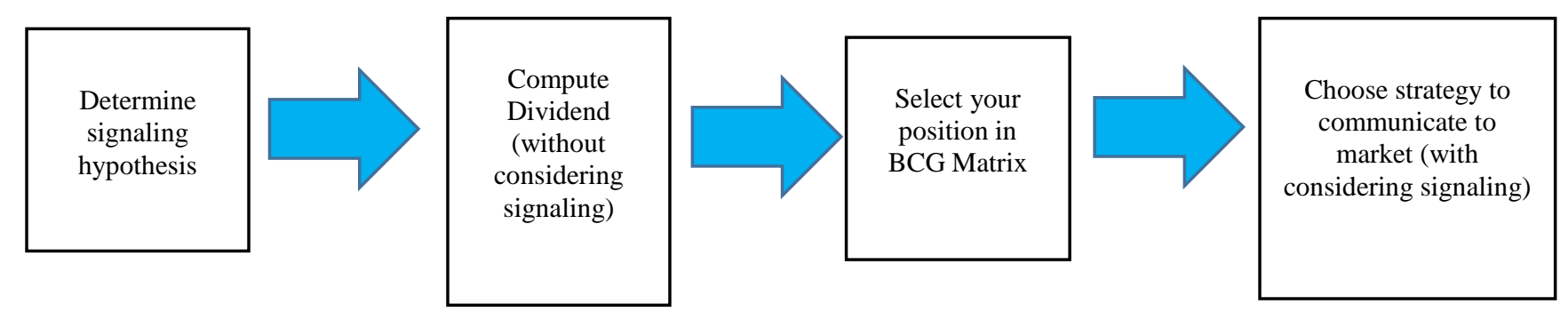

Figure 1.The process of applying signaling hypothesis to the firm 


\subsection{Determining signalling hypothesis}

For selecting the best strategy to react to the market by managers, First, we need to identify whether the signaling hypothesis is happen or not in a specific market. We want to uncover this hypothesis in one of the main emerging markets, Iran. Considering figure 1 for the main methodology that this paper is based on, this can be used in all markets and it is not limited to the example we go through. In this part, we mostly followed the methodology used in Nissim and Ziv (2001). We first start with more simple models, which actually may lead to erroneous results. Then we discuss the faults of these models and try to solve them to propose the final model.

Table 1. Statistic description of dividend events

\begin{tabular}{|c|c|c|c|c|}
\hline Year & Div-Inc & $\begin{array}{c}\text { Div_No } \\
\text { Change }\end{array}$ & Div-Dec & $\begin{array}{c}\text { Total Div } \\
\text { Events }\end{array}$ \\
\hline $2001-2002$ & 119 & 17 & 86 & 222 \\
\hline $2002-2003$ & 97 & 14 & 127 & 238 \\
\hline $2003-2004$ & 160 & 25 & 107 & 292 \\
\hline $2004-2005$ & 137 & 31 & 127 & 295 \\
\hline $2005-2006$ & 155 & 86 & 127 & 368 \\
\hline $2006-2007$ & 150 & 73 & 147 & 370 \\
\hline $2007-2008$ & 167 & 81 & 132 & 380 \\
\hline $2008-2009$ & 146 & 63 & 139 & 348 \\
\hline $2009-2010$ & 147 & 74 & 126 & 347 \\
\hline $2010-2011$ & 175 & 91 & 121 & 387 \\
\hline $2011-2012$ & 222 & 108 & 132 & 462 \\
\hline $2012-2013$ & 259 & 98 & 127 & 484 \\
\hline $2013-2014$ & 310 & 95 & 126 & 531 \\
\hline $2014-2015$ & 194 & 108 & 258 & 560 \\
\hline $2015-2016$ & 157 & 134 & 301 & 592 \\
\hline $2016-2017$ & 177 & 149 & 245 & 571 \\
\hline Total & 2772 & 1247 & 2428 & 6447 \\
\hline
\end{tabular}

The first method, assuming that the earnings follow a random walk process with a specific drift, uses a simple method like that of Benartzi (1997). In this model, the dependent variable is the changes in annual earnings deflated with price, and the rate of annual dividend changes is used as the independent variable. Specifically here, the relationship between dividend income change in year zero and the change in earnings in years zero, one, and two (deflated with the price at the beginning of the fiscal year of dividend distribution) is investigated, and the research question hypothesis will be tested. Therefore we regress the following equation for $\tau=0,1$, and 2 .

$$
\frac{E_{\tau}-E_{\tau-1}}{P_{-1}}=\alpha_{0}+\alpha_{1} R \Delta D I V_{0}+\varepsilon_{\tau}
$$

In this equation, $E_{\tau}$ denotes earnings in year ${ }^{\tau}, P_{-1}$ is the stock price at the beginning of the dividend change year, and $R \Delta D I V_{0}$ is the rate of change in dividend per share in the year zero.

Table 2 has the results of this pooled OLS. The first row reports the coefficient and the second row reports tstatistic. 
Conforming to Benartzi (1997), $\alpha_{1}$ is positive and highly significant for $\tau=0$, and it is not significant for $\tau=2$, but, contrary to their findings, it is also significant for $\tau=1$.

Table 2. Result of Model (1)

\begin{tabular}{|c|c|c|c|c|}
\hline \multicolumn{5}{|c|}{$\frac{E_{\tau}-E_{\tau-1}}{P_{-1}}=\alpha_{0}+\alpha_{1} R \Delta D I V_{0}+\varepsilon_{\tau}$} \\
\hline$\tau$ & $\alpha_{0}$ & $\alpha_{1}$ & $\mathrm{R}^{2}$ & $\mathrm{~N}$ \\
\hline \multirow{2}{*}{0} & -0.0146 & 0.0211 & \multirow{2}{*}{0.028} & \multirow{2}{*}{4639} \\
\hline & -2.253 & 11.469 & & \\
\hline \multirow{2}{*}{1} & 0.0015 & -0.005 & \multirow{2}{*}{0.002} & \multirow{2}{*}{4479} \\
\hline & 0.236 & -2.769 & & \\
\hline \multirow{2}{*}{2} & -0.0099 & -0.0028 & \multirow{2}{*}{0.001} & \multirow[b]{2}{*}{3957} \\
\hline & -1.495 & -1.49 & & \\
\hline
\end{tabular}

Nissim and Ziv vastly argue that this simple model has ample faults. Firstly, it may have a measurement error in the dependent variable. The change in the earnings in equation (1) is deflated by price at the beginning of dividend change year $\left(P_{-1}\right)$. Since price is reflecting stockholders' future predictions itself, abnormal positive (negative) change in earnings will indicate itself in rising (falling) prices. Therefore, the nominator and denominator of the independent variable in equation (1) are positively related to each other, and this measurement error may cause $\alpha_{1}$ to be biased against finding information content in dividends. Thus, we exchanged the $P_{-1}$ in this equation with $B_{-1}$, the book value of equity per share, which has no or little information about future earning changes as it changes once a year in Iran in most cases. Secondly, the assumption of earnings following a random walk pattern implies that the expected change in earnings may be zero (or constant if there is a drift). Nevertheless, in the presence of additional information about the company, this assumption may not hold anymore. Ohlson and Penman (1982) showed that ROE is an important predictor of changes in earnings. Based on their findings, ROE is mean reverting, which implies that low (high) earnings will follow high (low) levels of ROE. Hence, predicted changes in earning are negatively correlated with ROE. In order to solve the problem of this omitted correlated variable, ROE of the year $\tau-1$ has been added to the model as an independent regressor, and the following equation will be used for $\tau=0$ and 1 .

$$
\frac{E_{\tau}-E_{\tau-1}}{B_{-1}}=\alpha_{0}+\alpha_{1} R \Delta D I V_{0}+\alpha_{2} R O E_{\tau-1}+\varepsilon_{\tau}
$$

In this panel data, to address the problem of heteroscedasticity and autocorrelation in residuals, we incorporated the Fama-Macbeth two-step regression procedure.

We know that dividend changes are highly correlated with the contemporary (same year) earning changes. Therefore, if we had autocorrelation in earning change series, we would see significant relations between dividend changes and earning changes in subsequent years. In this regard, we added $\frac{E_{0}-E_{-1}}{B_{-1}}$ to the equation as a control variable to address this issue. Furthermore, it seems reasonable that the results about the information content of dividend changes may be asymmetric for dividend increases and decreases. Therefore, we add two binary dummy variables to separate the effect of these two events from each other, and we reach the following model for $\tau=0$ and 1 .

$$
\frac{E_{\tau}-E_{\tau-1}}{B_{-1}}=\alpha_{0}+\alpha_{1 p} D P C_{0} \cdot R \Delta D I V_{0}+\alpha_{1 n} D N C_{0} \cdot R \Delta D I V_{0}+\alpha_{2} R O E_{\tau-1}+\alpha_{3} \frac{E_{0}-E_{-1}}{B_{-1}}+\varepsilon_{\tau}
$$


In table 3, which will be provided further, we have the results of pooled and cross-sectional OLS regressions of models (2) and (3) including t-statistic for each coefficient and proportion of positive coefficients in each crosssectional regression. In the analysis of cross-sectional regressions, we have used Fama-Macbeth method.

According to the results (Table3), none of the coefficients in model 2 is statistically significant, meaning that, based on this model, in the Iranian stock market, the dividend change rate, as well as the ROE, provides no useful information about changes in earnings (adjusted to book value) in the coming years. The reason for this observation can be the homogeneity of the book value of equity in the Iranian market, which extracts out the explanatory power from these variables. Particularly, because of the high inflation that exists in Iran, usually after a few years, the book value of equity per share will be completely irrelevant to the real value of equity since firms usually do not revise their capital in their balance sheet regularly. It should be noted, however, in the cross-sectional analysis, it was observed that these coefficients were statistically significant in some of the years while not in aggregation.

Table 3. Result from Model (2) and Model (3)

\begin{tabular}{|c|c|c|c|c|c|c|c|}
\hline \multicolumn{8}{|c|}{ Panel $-A: \frac{\left(E_{t}-E_{t-1}\right)}{B_{-1}}=\alpha_{0}+\alpha_{1} R \Delta D I V_{0}+\alpha_{2} R O E_{t-1}+\varepsilon_{t}$} \\
\hline \multirow{4}{*}{\multicolumn{2}{|c|}{ Pooled }} & $\alpha_{0}$ & $\alpha_{1}$ & $\alpha_{2}$ & $\mathrm{R}^{2}$ & \multicolumn{2}{|c|}{$\mathrm{N}$} \\
\hline & & \multicolumn{6}{|c|}{$t=1$} \\
\hline & & 0.571 & -0.045 & 0.000 & \multirow{2}{*}{0.000} & \multirow{2}{*}{\multicolumn{2}{|c|}{4944}} \\
\hline & & 0.903 & -0.425 & -0.157 & & & \\
\hline \multicolumn{8}{|l|}{$\mathrm{CS}$} \\
\hline & & -0.101 & -0.041 & 0.017 & \multirow{3}{*}{0.117} & \multirow{3}{*}{\multicolumn{2}{|c|}{309}} \\
\hline & & -0.763 & -1.148 & 1.023 & & & \\
\hline \multicolumn{2}{|c|}{ Prop+ } & 0.438 & 0.313 & 0.375 & & & \\
\hline \multicolumn{8}{|c|}{$t=2$} \\
\hline \multirow{2}{*}{\multicolumn{2}{|c|}{ Pooled }} & -0.453 & -0.011 & 0.000 & \multirow{2}{*}{0.000} & \multirow{2}{*}{\multicolumn{2}{|c|}{4367}} \\
\hline & & -1.118 & -0.167 & -0.180 & & & \\
\hline \multicolumn{8}{|l|}{$\mathrm{CS}$} \\
\hline & & -0.488 & 0.006 & 0.000 & \multirow{3}{*}{0.012} & \multirow{3}{*}{\multicolumn{2}{|c|}{291}} \\
\hline & & -1.098 & 0.285 & 0.081 & & & \\
\hline & & 0.429 & 0.143 & 0.714 & & & \\
\hline \multicolumn{8}{|c|}{$\frac{E_{\tau}-E_{\tau-1}}{B_{-1}}=\alpha_{0}+\alpha_{1 p} D P C_{0} \cdot R \Delta D I V_{0}+\alpha_{1 n} D N C_{0} \cdot R \Delta D I V_{0}+\alpha_{2} R O E_{\tau-1}+\alpha_{3} \frac{E_{0}-E_{-1}}{B_{-1}}+\varepsilon_{\tau}$} \\
\hline \multicolumn{8}{|c|}{$t=1$} \\
\hline mean & 0.031 & -0.005 & 0.034 & -0.001 & -0.107 & \multirow{3}{*}{0.371} & \multirow{3}{*}{309} \\
\hline t-stat & 0.609 & -0.663 & 0.266 & -1.415 & -0.502 & & \\
\hline Prop+ & 0.500 & 0.313 & 0.563 & 0.250 & 0.375 & & \\
\hline \multicolumn{8}{|c|}{$t=2$} \\
\hline mean & -0.010 & -0.007 & 0.002 & 0.000 & -0.165 & \multirow{3}{*}{0.206} & \multirow{3}{*}{291} \\
\hline t-stat & -0.271 & -1.312 & 0.025 & 0.381 & -0.843 & & \\
\hline Prop+ & 0.267 & 0.533 & 0.400 & 0.267 & 0.400 & & \\
\hline
\end{tabular}

So far, in all three models, we just dealt with rates; in other words, earnings were deflated by a related value in all models. Now, it comes to mind why we do not regress the level of earnings on the level of changes in dividends. Therefore, now we put earnings as the dependent variable in our model. To make sure about the unbiasedness of estimators, we control for the current year earning $\left(E_{0}\right)$. Moreover, we generally add three 


\section{ENTREPRENEURSHIP AND SUSTAINABILITY ISSUES}

ISSN 2345-0282 (online) http://jssidoi.org/jesi/ 2020 Volume 8 Number 2 (December) http://doi.org/10.9770/jesi.2020.8.2(1)

categories of control variables: past accounting variables such as book value per share at the beginning of the dividend change year $\left(B_{-1}\right)$ and the earning in that year $\left(E_{-1}\right)$, the market price of stocks $\left(P_{-1}\right)$, and the changes in dividend level $\left(\Delta D I V_{0}\right)$. Like in the model (3), we allow for different coefficients on past dividend increases and decreases. We will test the following equation coefficients for $\tau=1,2,3,4$, and 5 .

$$
\begin{gathered}
E_{\tau}=\beta_{0}+\beta_{1 \tau} D P C_{0} \cdot \Delta D I V_{0}+\beta_{2 \tau} D N C_{0} \cdot \Delta D I V_{0}+\beta_{3 \tau} E_{-1}+\beta_{4 \tau} B_{-1}+\beta_{5 \tau} P_{-1}+\beta_{6 \tau} D I V_{-1}+\beta_{7 \tau} D P C_{-1} \cdot \Delta D I V_{-1} \\
+\beta_{8 \tau} D N C_{-1} \cdot \Delta D I V_{-1}+\beta_{9 \tau} E_{0}+\varepsilon_{\tau}
\end{gathered}
$$

The results of the regressions in the model (4) are shown in table 4. Further, we designed a panel data and used Fama-Macbeth procedure. In this model, the variable $D P C_{0} . \Delta D I V_{0}$ is not so meaningful, but the variable $D N C_{0} \cdot \Delta D I V_{0}$ in the third column has very meaningful results, suggesting/which suggests that dividend increases in Iran appear to be not necessarily indicative of future increasing revenues, but a reduction in dividends is a significant sign of a decline in future earnings of up to five years. It is only significant at the confidence level of $10 \%$ for the first year, but for the next years, it is significant at almost every level. Note that this result is precisely the opposite of the result that Nissim and Ziv (2001) came to in the US stock market. Also, in this regression of model 4 , the three variables of past year dividend, share prices at the beginning of current year and last year's earnings have significant explanatory power, which, according to their definitions, is not surprising and is entirely justifiable.

The possibly wrong hidden assumption behind this model is that it has posed inflation to be low and not fluctuate so much because it is regressing the earnings of up until five years on some variables of the current year. However, the time value of money may bear harsh changes during even one or two years in Iran, a country which underwent consecutive over-thirty-percent inflations in some years. Therefore, the minimum expectation of people in Iran from earnings growth in future years is the compounded inflation rate of those years.

Therefore, since Iran has been experiencing significant inflation rate every year for at least the last two decades, inflation seems to have a direct impact on investors' expectation of future profitability and it should be taken into account in the model under consideration. In this regard, the question that arises at this stage of our research is how to account for the effect of inflation on investors' expectation of future profitability, and possibly on corporate managers' motivation to increase dividends.

In the Nissim and Ziv (2001) method, probably due to the relatively constant, low level of inflation in the United States (averaging below 2\% per year in the last decade), there was no need for incorporating inflation rate into the analytical model or preparing the input data structures. For example, in an economy experiencing low inflation, dividend increases -even as small as 10 cents- are considered a real increase in dividends by investors. Nevertheless, in a country such as Iran whose economy has a high and varying inflation rate, at the end of a fiscal year, not only is a 50 IRR dividend increase of a share not considered as an increase, but perhaps a reduction in that dividends' real value as well. 
ENTREPRENEURSHIP AND SUSTAINABILITY ISSUES

ISSN 2345-0282 (online) http://jssidoi.org/jesi/ 2020 Volume 8 Number 2 (December) http://doi.org/10.9770/jesi.2020.8.2(1)

Table 4. Result of model 4

\begin{tabular}{|c|c|c|c|c|c|c|c|c|c|c|c|c|c|}
\hline \multicolumn{14}{|c|}{$\begin{array}{c}E_{\tau}=\beta_{0}+\beta_{1 \tau} D P C_{0} \cdot \Delta D I V_{0}+\beta_{2 \tau} D N C_{0} \cdot \Delta D I V_{0}+\beta_{3 \tau} E_{-1}+\beta_{4 \tau} B_{-1}+\beta_{5 \tau} P_{-1}+\beta_{6 \tau} D I V_{-1} \\
+\beta_{7 \tau} D P C_{-1} \cdot \Delta D I V_{-1}+\beta_{8 \tau} D N C_{-1} \cdot \Delta D I V_{-1}+\beta_{9 \tau} E_{0}+\varepsilon_{\tau}\end{array}$} \\
\hline & Stat. & $\beta_{0}$ & $\beta_{1 \tau}$ & $\beta_{2 \tau}$ & $\beta_{3 \tau}$ & $\beta_{4 \tau}$ & $\beta_{5 \tau}$ & $\beta_{6 \tau}$ & $\beta_{7 \tau}$ & $\beta_{8 \tau}$ & $\beta_{9 \tau}$ & $R^{2}$ & $\mathrm{~N}$ \\
\hline \multirow[t]{3}{*}{1} & Mean & 99.974 & 0.116 & 0.226 & -0.024 & 0.015 & 0.004 & 0.298 & -0.201 & -0.034 & 0.581 & \multirow{3}{*}{0.592} & \multirow{3}{*}{266} \\
\hline & t-stat & 2.471 & 0.922 & 1.939 & -0.563 & 0.942 & 1.277 & 3.010 & -1.626 & -1.080 & 6.710 & & \\
\hline & Prop+ & 0.667 & 0.667 & 0.667 & 0.400 & 0.600 & 0.600 & 0.667 & 0.400 & 0.333 & 1.000 & & \\
\hline 2 & Mean & 177.795 & 0.059 & 0.475 & 0.024 & 0.001 & 0.014 & 0.474 & -0.368 & 0.036 & 0.298 & \multirow{3}{*}{0.435} & \multirow{3}{*}{254} \\
\hline & t-stat & 3.263 & 0.417 & 3.963 & 0.435 & 0.028 & 2.219 & 4.322 & -3.497 & 0.869 & 3.553 & & \\
\hline & Prop+ & 0.786 & 0.500 & 0.714 & 0.357 & 0.571 & 0.714 & 0.857 & 0.214 & 0.714 & 0.786 & & \\
\hline \multirow[t]{3}{*}{3} & Mean & 228.502 & -0.086 & 0.697 & -0.002 & -0.016 & 0.021 & 0.559 & -0.327 & -0.044 & 0.185 & \multirow{3}{*}{0.344} & \multirow{3}{*}{241} \\
\hline & t-stat & 4.579 & -0.783 & 5.667 & -0.031 & -0.835 & 2.539 & 4.906 & -2.611 & -0.981 & 3.035 & & \\
\hline & Prop+ & 0.769 & 0.385 & 1.000 & 0.462 & 0.462 & 0.692 & 0.923 & 0.231 & 0.462 & 0.769 & & \\
\hline \multirow[t]{3}{*}{4} & Mean & 220.698 & -0.032 & 0.619 & -0.100 & 0.010 & 0.017 & 0.679 & -0.415 & -0.062 & 0.127 & \multirow{3}{*}{0.284} & \multirow{3}{*}{230} \\
\hline & t-stat & 3.844 & -0.355 & 8.288 & -1.480 & 0.285 & 1.748 & 5.497 & -2.568 & -1.091 & 2.554 & & \\
\hline & Prop+ & 0.833 & 0.417 & 0.917 & 0.417 & 0.500 & 0.750 & 1.000 & 0.333 & 0.333 & 0.750 & & \\
\hline \multirow[t]{3}{*}{5} & Mean & 305.537 & 0.050 & 0.573 & 0.068 & -0.061 & 0.027 & 0.601 & -0.247 & 0.068 & 0.026 & \multirow{3}{*}{0.267} & \multirow{3}{*}{221} \\
\hline & t-stat & 5.532 & 0.499 & 3.791 & 0.879 & -2.193 & 3.733 & 4.794 & -1.744 & 0.609 & 0.446 & & \\
\hline & Prop+ & 0.818 & 0.455 & 0.909 & 0.545 & 0.364 & 0.727 & 0.909 & 0.455 & 0.273 & 0.455 & & \\
\hline
\end{tabular}

Therefore, in the present study, we used a method to examine the effect of inflation on increasing investors' expectation of dividends growth. To study the Iranian market, which is undergoing high inflation rates, we selected a base year, the year 2001, and deflated all financial variables (amounts not rates) in the rest of the years to this base year with a compounded rate of annual inflation rates. For example, variables of the year 2003 are deflated to the base year 2001 with the year 2002 and 2003 inflation rates. In Iran, the Central Bank and Iranian Statistics Center, independently report inflation each year. We selected the inflation rates reported by the Central Bank of Iran, rearrange the data into the discounted variables, and re-ran the model 4 with this new deflated dataframe. in this model, named model 5 the statistic description of the dividend events are put in the table 5 - equivalent to table 1 for the deflated dividends- and coefficients of variables and test statistics are reported in the table 6 . bear in mind that the equation for model 5 is the same as the equation in model and just the data is different. 
ENTREPRENEURSHIP AND SUSTAINABILITY ISSUES

ISSN 2345-0282 (online) http://jssidoi.org/jesi/ 2020 Volume 8 Number 2 (December) http://doi.org/10.9770/jesi.2020.8.2(1)

Table 5. Statistic description of dividend events after deflation

\begin{tabular}{|c|c|c|c|c|}
\hline Year & Div-Inc & $\begin{array}{c}\text { Div_No } \\
\text { Change }\end{array}$ & Div-Dec & $\begin{array}{c}\text { Total Div } \\
\text { Events }\end{array}$ \\
\hline $2001-2002$ & 47 & 4 & 143 & 194 \\
\hline $2002-2003$ & 90 & 6 & 136 & 232 \\
\hline $2003-2004$ & 100 & 10 & 140 & 250 \\
\hline $2004-2005$ & 104 & 21 & 152 & 277 \\
\hline $2005-2006$ & 122 & 31 & 174 & 327 \\
\hline $2006-2007$ & 117 & 31 & 186 & 334 \\
\hline $2007-2008$ & 77 & 30 & 199 & 306 \\
\hline $2008-2009$ & 115 & 42 & 151 & 308 \\
\hline $2009-2010$ & 131 & 46 & 149 & 326 \\
\hline $2010-2011$ & 137 & 49 & 181 & 367 \\
\hline $2011-2012$ & 183 & 50 & 187 & 420 \\
\hline $2012-2013$ & 218 & 47 & 199 & 464 \\
\hline $2013-2014$ & 144 & 46 & 307 & 497 \\
\hline $2014-2015$ & 113 & 79 & 336 & 528 \\
\hline $2015-2016$ & 151 & 87 & 279 & 517 \\
\hline $2016-2017$ & 1999 & 580 & 2924 & 5503 \\
\hline
\end{tabular}

As can be seen, taking into account the effect of inflation in subsequent years has caused a significant change in the results of the tables. The DNC0* $\triangle \mathrm{DIV0}$ variable, as before, has been significant over the next five years with relatively large test statistics and positive coefficients. This result indicates that if the real value of the dividend (the deflated amount) declines, the market will react negatively because it will be a relatively strong indication of a decline in the firm's future profitability. At the same time, we found that none of the cells in the column associated with the dividend increase are significant, and they have very small test statistics. It shows that the occasional dividend increases in Iran had no indication of future profitability increases, possibly because the firms did not have projects with a positive NPV in hand that needs cash. Thus, there is no need for shareholders money, and it is better to return it to its owners so that stock prices will not fall next year. 
ENTREPRENEURSHIP AND SUSTAINABILITY ISSUES

ISSN 2345-0282 (online) http://jssidoi.org/jesi/ 2020 Volume 8 Number 2 (December) http://doi.org/10.9770/jesi.2020.8.2(1)

Table 6. Result after inflation

\begin{tabular}{|c|c|c|c|c|c|c|c|c|c|c|c|c|c|}
\hline \multicolumn{14}{|c|}{$\begin{array}{c}E_{\tau}=\beta_{0}+\beta_{1 \tau} D P C_{0} \cdot \Delta D I V_{0}+\beta_{2 \tau} D N C_{0} \cdot \Delta D I V_{0}+\beta_{3 \tau} E_{-1}+\beta_{4 \tau} B_{-1}+\beta_{5 \tau} P_{-1}+\beta_{6 \tau} D I V_{-1} \\
+\beta_{7 \tau} D P C_{-1} \cdot \Delta D I V_{-1}+\beta_{8 \tau} D N C_{-1} \cdot \Delta D I V_{-1}+\beta_{9 \tau} E_{0}+\varepsilon_{\tau}\end{array}$} \\
\hline & Stat. & $\beta_{0}$ & $\beta_{1 \tau}$ & $\beta_{2 \tau}$ & $\beta_{3 \tau}$ & $\beta_{4 \tau}$ & $\beta_{5 \tau}$ & $\beta_{6 \tau}$ & $\beta_{7 \tau}$ & $\beta_{8 \tau}$ & $\beta_{9 \tau}$ & $R^{2}$ & $\mathrm{~N}$ \\
\hline \multirow{3}{*}{1} & Mean & 42.996 & 0.135 & 0.180 & -0.009 & 0.013 & 0.003 & 0.262 & -0.195 & 0.390 & 0.464 & \multirow{3}{*}{0.612} & \multirow{3}{*}{244} \\
\hline & t-stat & 2.311 & 1.055 & 2.097 & -0.291 & 1.168 & 1.142 & 3.069 & -2.036 & 1.000 & 6.262 & & \\
\hline & Prop+ & 0.600 & 0.667 & 0.733 & 0.533 & 0.600 & 0.667 & 0.733 & 0.333 & 0.400 & 1.000 & & \\
\hline \multirow{3}{*}{2} & Mean & 59.222 & 0.040 & 0.347 & 0.027 & 0.003 & 0.009 & 0.349 & -0.272 & 0.302 & 0.172 & \multirow{3}{*}{0.442} & \multirow{3}{*}{236} \\
\hline & t-stat & 3.063 & 0.344 & 4.202 & 0.734 & 0.197 & 2.225 & 4.727 & -3.478 & 1.109 & 3.182 & & \\
\hline & Prop+ & 0.857 & 0.500 & 0.786 & 0.429 & 0.571 & 0.714 & 0.929 & 0.286 & 0.714 & 0.786 & & \\
\hline \multirow{3}{*}{3} & Mean & 72.520 & -0.101 & 0.330 & -0.007 & -0.013 & 0.011 & 0.265 & -0.165 & 0.785 & 0.128 & \multirow{3}{*}{0.344} & \multirow{3}{*}{226} \\
\hline & t-stat & 4.244 & -1.307 & 5.836 & -0.227 & -1.240 & 2.852 & 4.938 & -2.124 & 1.122 & 3.319 & & \\
\hline & Prop+ & 0.846 & 0.385 & 1.000 & 0.462 & 0.385 & 0.769 & 0.923 & 0.308 & 0.462 & 0.769 & & \\
\hline \multirow{3}{*}{4} & Mean & 58.471 & -0.038 & 0.274 & -0.063 & 0.004 & 0.008 & 0.373 & -0.265 & 0.354 & 0.061 & \multirow{3}{*}{0.280} & \multirow{3}{*}{215} \\
\hline & t-stat & 3.680 & -0.815 & 8.026 & -1.968 & 0.236 & 2.002 & 5.755 & -3.595 & 1.171 & 3.103 & & \\
\hline & Prop+ & 0.833 & 0.333 & 0.917 & 0.250 & 0.500 & 0.833 & 1.000 & 0.167 & 0.500 & 0.833 & & \\
\hline \multirow{3}{*}{5} & Mean & 71.186 & 0.007 & 0.243 & 0.036 & -0.029 & 0.009 & 0.219 & -0.068 & 0.246 & 0.000 & \multirow{3}{*}{0.258} & \multirow{3}{*}{208} \\
\hline & t-stat & 5.239 & 0.160 & 5.473 & 1.255 & -3.578 & 3.906 & 4.291 & -1.314 & 1.359 & -0.004 & & \\
\hline & Prop+ & 1.000 & 0.455 & 0.909 & 0.545 & 0.182 & 1.000 & 0.818 & 0.545 & 0.545 & 0.545 & & \\
\hline
\end{tabular}

Due to the autocorrelation of these two variables, the lags of these two variables were also included in the model. As can be seen, these later variables are statistically significant in contrast to the current year variables. Lag of increment DPC- $1^{*} \Delta \mathrm{DIV}-1$ is significant up to four years with negative coefficients. In other words, dividend increases have a declining effect on future profitability with one year delay, which is fully explained by the DPC $0^{*} \triangle \mathrm{DIV} 0$ that indicates dividend increases are probably due to the lack of positive NPV projects and no need for liquidity. The decreasing dividend lag of DNC-1* $\Delta \mathrm{DIV}-1$ has not been significant in any year, which is well justified by the significance of the DNC $0^{*} \Delta \mathrm{DIV} 0$ variable in all of the years. In other words, the present variable has absorbed all the effects related to reducing the dividend. The control variables P-1, B-1, E1, and E0 have been meaningful for some years as expected of their controlling role, which is in line with our expectation that these variables were actually included in the model to assure accuracy. The $\mathrm{R}^{2}$ variable is about $61 \%$ in the first year and $44 \%$ in the second year, with a downward trend to the fifth year, which is exactly what we expect, and as we move away from the current year, this variable will show less explanatory power of the current year variables for future earnings. The level of $\mathrm{R}^{2}$ in the early years is quite acceptable, and this indicates that the variables of this model have explained a significant portion of the level of profitability and its changes over the years. 


\section{ENTREPRENEURSHIP AND SUSTAINABILITY ISSUES}

ISSN 2345-0282 (online) http://jssidoi.org/jesi/ 2020 Volume 8 Number 2 (December) http://doi.org/10.9770/jesi.2020.8.2(1)

\section{4-3.Dividend Strategy selection for communicating the Market}

According to figure one, we are now in a place to go forward.Managers can react to the signalling hypothesis for better communicating dividend strategies or even cheating the market. In addition, shareowners must predict this reaction to better understanding the managers for lowering agency costs. For discovering different scenarios, we must identify the position of the firm in the BCG Growth-share Matrix or equivalently in Industry life cycle model. Henderson(1979) argued that a business can position itself in one of the four items in a corporate portfolio.Also in an imaginary corporate one can imagine a corporate having only one business and position a business to find what strategy can use to enhance competitive advantage. For instance, a new company would be in question mark and after analysing the market can go to the Star position if shareowners invest enough amount of money to expand the market. When the market is matured, the business go to the cash cow position to Milk the owners with profit distribution and not investing anymore .In the End the shareowners must sell the business when it goes in the Dog position.Figure two better describe BCG growth-share Matrix.

\begin{tabular}{|c|c|c|c|}
\hline \multirow{2}{*}{ 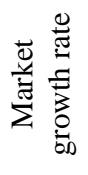 } & High & Question Mark & Star \\
\hline & Low & Dog & Cash Cow \\
\hline \multirow{2}{*}{\multicolumn{2}{|c|}{$\begin{array}{l}\text { BCG growth } \\
\text {-share Matrix }\end{array}$}} & Low & High \\
\hline & & \multicolumn{2}{|c|}{ Relative market share } \\
\hline
\end{tabular}

Figure 2. BCG growth-share matrix (Henderson, 1979)

For using the BCG the growth-share matrix in dividend strategy selection, First we compute the amount of dividend that a firm is planed to pay before knowing about the signaling hypothesis. It means the the company must compute the real dividend that they want to pay to shareowners regardless of knowing the result of the signaling hypothesis in the market (the right side of figure three). Second, we position the firm in the matrix. Third ,a manager could use the knowledge of signaling hypothesis to change the communication plan with the market based on the position the company has in the BCG growth-share matrix (the left side of figure three). Figure three shows the difference between what is want to do in dividend strategy before and after identifying the signaling hypothesis in the market. We assume that one of the four conditions could happen. We use the first category if the signaling hypothesis is not supported in any directions. In the second category, market data reveal there is signaling when the dividend gets increased and earning would be higher in the future but lowering dividend is not related to future earning. In the third category, decreasing the dividend is a signal of a lowering earning in near future but increasing dividend shows nothing to happen in the near future. In the last category, one can identify signaling in both directions and it means if we increase the dividend, the earning will be higher in near future and if we decrease the dividend, the earning will be lower in the next few years. For driling down more we go through each condition in detail:

\section{No signaling identified}

In this condition, what managers do in before and after signaling identification are the same in every level of the BCG Growth-share Matrix.There is no cheating potential and shareowners can trust whatever managers would claim about dividend.Equation 5 can explain this behavior in detail: 


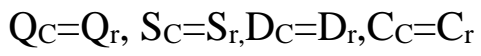

Where:

$\mathrm{Q}_{\mathrm{r}}$ is the real dividend in the question mark position

$\mathrm{Q}_{\mathrm{C}}$ is the communicated dividend in the question mark position

$\mathrm{S}_{\mathrm{r}}$ is the real dividend in the star position

$\mathrm{S}_{\mathrm{C}}$ is the communicated dividend in the Star position

$\mathrm{D}_{\mathrm{r}}$ is the real dividend in the dog position

$\mathrm{D}_{\mathrm{c}}$ is the communicated dividend in the dog position

$\mathrm{C}_{\mathrm{r}}$ is the real dividend in the cash cow position

$\mathrm{C}_{\mathrm{C}}$ is the communicated dividend in the cash cow position

It is needed to say that based on the logic of the BCG Growth-share Matrix,the amount of dividend increase from the question mark to the star and form the star to the cash-cow.But it decrease from the cash Cow to the dog .In brief equation 6 is true in real cases.

$$
\begin{gathered}
\mathrm{Q}_{\mathrm{r}}=0,0=<\mathrm{S}_{\mathrm{r}}<=\mathrm{C}_{\mathrm{r}}, \mathrm{D}_{\mathrm{r}}<=\mathrm{C}_{\mathrm{r}} \\
\mathrm{D}_{\mathrm{r}}=\left\langle\mathrm{C}_{\mathrm{r}}>=\mathrm{S}_{\mathrm{r}}>=\mathrm{Q}_{\mathrm{r}}\right.
\end{gathered}
$$

\section{Only increase signaling identified}

In this condition, if managers increase the dividend to deviate from the real dividend(that is computed before signaling identified), market (including shareowners) expect for increase earning in the near future so if firm locate in the question mark and the star cell would cheat the market and benefit for attracting huge amounts of investment because of incorrect signals. Also in the cash cow position the value of the company would go up incorrectly for pretending better future that shareowners could assume. Furthermore, in the dog position managers can have enough time for finding a buyer for the whole company to divest from industry.

Managers could cheat shareowners especially in the dog position when the company can pretend to be valuable by increasing dividend to shareowners when it is logically false for that position.

Shareowners cannot identify the exact position of the company (the dog vs the cash cow) when increase signaling happens and managers increase the dividend to cheat shareowners subsequently.Equation seven can show this unreal future that managers can make for shareowners in simple equations. Comparing equation six (the real) and seven (unreal for better communication using signaling hypothesis) can show cheating potential evidently.

$$
\begin{gathered}
\mathrm{Q}_{\mathrm{C}}>=\mathrm{Q}_{\mathrm{r}}, \mathrm{S}_{\mathrm{C}}>=\mathrm{S}_{\mathrm{r}} \mathrm{D}_{\mathrm{C}}>=\mathrm{D}_{\mathrm{r}}, \mathrm{C}_{\mathrm{C}}>=\mathrm{C}_{\mathrm{r}} \\
\mathrm{D}_{\mathrm{C}}>=\mathrm{C}_{\mathrm{C}}>=\mathrm{S}_{\mathrm{C}}>=\mathrm{Q}_{\mathrm{C}}
\end{gathered}
$$


Dividend policy before considering signaling hypothesis

\section{Dividend policy after considering} signaling hypothesis

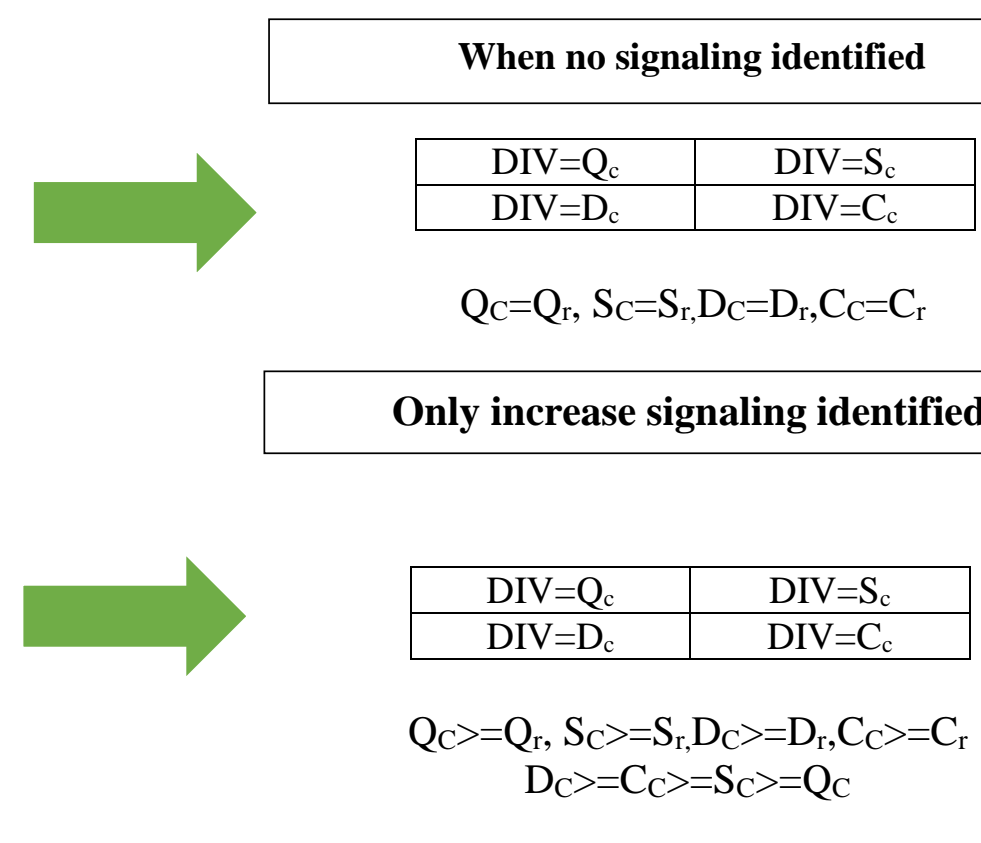

Only decrease signaling identified

$\mathrm{Q}_{\mathrm{r}}=0,0=<\mathrm{S}_{\mathrm{r}}<=\mathrm{C}_{\mathrm{r}}, \mathrm{D}_{\mathrm{r}}<=\mathrm{C}_{\mathrm{r}}$ $\left.\mathrm{D}_{\mathrm{r}}=\left\langle\mathrm{C}_{\mathrm{r}}\right\rangle=\mathrm{S}_{\mathrm{r}}\right\rangle=\mathrm{Q}_{\mathrm{r}}$

\begin{tabular}{|l|l|}
\hline $\mathrm{DIV}=\mathrm{Q}_{\mathrm{r}}$ & $\mathrm{DIV}=\mathrm{S}_{\mathrm{r}}$ \\
\hline $\mathrm{DIV}=\mathrm{D}_{\mathrm{r}}$ & $\mathrm{DIV}=\mathrm{C}_{\mathrm{r}}$ \\
\hline
\end{tabular}

\section{When no signaling identified}

\begin{tabular}{|l|l|}
$\mathrm{DIV}=\mathrm{Q}_{\mathrm{c}}$ & $\mathrm{DIV}=\mathrm{S}_{\mathrm{c}}$ \\
\hline $\mathrm{DIV}=\mathrm{D}_{\mathrm{c}}$ & $\mathrm{DIV}=\mathrm{C}_{\mathrm{c}}$ \\
\hline
\end{tabular}

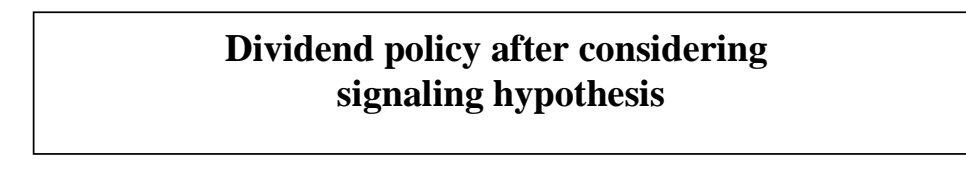

.

d




\section{Only decrease signaling identified}

In this condition, decreasing signaling can tell about bad earning in the future over the market. By understanding having decrease signaling potential in the market, managers would not decrease the dividend for protecting the firm for bad signals. In addition, they would not increase the dividend because of not signaling potential in the market. Therefore, equation eight could be true and no change between real and communicating dividend occur. The most important phenomenon that is shown in equation 8 is the equality between the cash cow and the dog dividend. This is the result of cheating potential that decreasing the amount of dividend could signal to the market for the dog position and managers do not want to communicate this truth to shareowners.

$$
\begin{gathered}
\mathrm{Q}_{\mathrm{C}}=\mathrm{Q}_{\mathrm{r}}, \mathrm{S}_{\mathrm{C}}=\mathrm{S}_{\mathrm{r},} \mathrm{D}_{\mathrm{C}}=\mathrm{D}_{\mathrm{r}}, \mathrm{C}_{\mathrm{C}}=\mathrm{C}_{\mathrm{r}} \\
\mathrm{D}_{\mathrm{C}}=\mathrm{C}_{\mathrm{C}}>=\mathrm{S}_{\mathrm{C}}>=\mathrm{Q}_{\mathrm{C}}
\end{gathered}
$$

\section{Signaling identified in both direction}

As managers know that signaling is identified in both directions, they could increase dividend for using signaling potential whenever possible. In addition, they do not decrease the amount of the dividend even in the dog cell of the BCG growth-matrix.Thus equation nine can result from this situation and the cheating potential exists the same as previous conditions but in a more and serious way.

$$
\begin{gathered}
\mathrm{Q}_{\mathrm{C}}>=\mathrm{Q}_{\mathrm{r}}, \mathrm{S}_{\mathrm{C}}>=\mathrm{S}_{\mathrm{r},} \mathrm{D}_{\mathrm{C}}>=\mathrm{D}_{\mathrm{r}}, \mathrm{C}_{\mathrm{C}}>=\mathrm{C}_{\mathrm{r}} \\
\mathrm{D}_{\mathrm{C}}>=\mathrm{C}_{\mathrm{C}}>=\mathrm{S}_{\mathrm{C}}>=\mathrm{Q}_{\mathrm{C}}
\end{gathered}
$$

\section{Conclusions, managerial implication and Limitations}

In this paper, we go to the process of applying the signaling hypothesis to the firm (figure two) that is fully described and applied in the whole paper. First, we analyze the Iranian stock market as an example of an emerging market that is rarely investigated for signaling hypothesis in previous research. We show that an increasing amount of the dividend has no signal to shareowners but decrease the payment to stock owners have a great signal (empirical contribution). Then we show that managers could cheat shareowners based on the position they have in the BCG Growth-Share Matrix (theoretical contribution). Based on our analysis in the example of the Iranian Market we must use the third scenario and take care of the dog position that managers could preserve payment to a dividend to pretend their business is going well as the cash cow position (managerial implication). This research shows and predicts the agency cost that managers can make for shareowners when they identified the signaling hypothesis is working in the stock market (theoretical contribution).

We have some limitations in our research. Prior empirical research show in most cases we have positive signaling or no signaling in the market. Therefore, all Scenarios we analyze in figure three assume managers want to react to positive signaling. In rare cases, we can identify negative signaling in the market, where increasing dividend signals negatively to the market, for instance, decreasing in earning and lowering the total value of the firm. In that case, you must analyze again and re-write the analysis. In this research, we forecast the managerial reactions 


\section{ENTREPRENEURSHIP AND SUSTAINABILITY ISSUES}

ISSN 2345-0282 (online) http://jssidoi.org/jesi/ 2020 Volume 8 Number 2 (December) http://doi.org/10.9770/jesi.2020.8.2(1)

to the signaling hypothesis for the first time. I propose other researchers to test this modeling by analyzing managers in their market for better understanding the mechanisms and chains of actions and reactions.

\section{References}

Abdulla, J. (2016). Focus on dividend practices of Omani firms: Survey findings. Journal of Finance Management and Analysis, 29(2). https://ssrn.com/abstract=2965675

Adelegan, O. J. (2003). An Empirical Analysis of the Relationship between Cash Flow and Dividend Changes in Nigeria. African Development Review, 15, 35-49. https://doi.org/10.1111/1467-8268.00061

Aharony, J., Falk, H., \& Swary, I. (1988). Information content of dividend increases: The case of regulated utilities. Journal of Business Finance and Accounting, 15(3), 401-14. https://doi.org/10.1111/j.1468-5957.1988.tb00143.x

Ahmed, H. \& Attiya, J. (2009). Dynamics and determinants of dividend policy in Pakistan (evidence from Karachi Stock Exchange nonfinancial firms). International Journal of Finance and Economics, 25, 148-171. Retrived from https://mpra.ub.uni-muenchen.de/37342/

Afza, T. \& Mirza, H. (2010). Ownership structure and cash flows as determinants of corporate dividend policy in Pakistan. International Business Research, 3(3). https://doi.org/10.5539/ibr.v3n3p210

Aivazian, V., Booth, L., \& Cleary, S. (2003). Do emerging market firms follow different dividends policies from US firms?. The Journal of Financial Research, 26(4), 371-387. https://doi.org/10.1111/1475-6803.00064

Al-Najjar, B. (2009). Dividend behaviour and smoothing: new evidence from Jordanian panel data. Studies in Economics and Finance, 26(3), 182-197. https://doi.org/10.1108/10867370910974017

Al-Qudah, A., \& Badawi, A. (2015). The Signaling Effects and Predictive Powers of Dividend Announcements: Evidence from Kingdom of Saudi Arabia. Journal of Business and Economics, 6(3), 550-557. https://doi.org/10.15341/jbe(2155-7950)/03.06.2015/012

Al-Yahyaee, K., Pham, T. \& Walter, T. (2006). Capital structure and dividend policy in a personal tax free environment: the case of Oman. Unpublished PhD. Dissertation, University of New South Wales.

Al-Shattarat, W., Al-Shattarat, B., \& Hamed, H. (2018). Do dividends announcements signal future earnings changes for Jordanian firms?. Journal of Financial Reporting and Accounting, 16(3), 417-442. https://doi.org/10.1108/JFRA-03-2017-0021

Baker, H.K, Dewasiri, N., Yatiwelle Koralalage, W. \& Azeez, A. (2019). Dividend policy determinants of Sri Lankan firms: a triangulation approach. Managerial Finance, 45(1), 2-20. https://doi.org/10.1108/MF-03-2018-0096

Baker, H.K., \& Jabbouri, I. (2016). How Moroccan managers view dividend policy. Managerial Finance, 42(3), 270-288. https://doi.org/10.1108/MF-07-2015-0211

Baker, H.K., \& Jabbouri, I. (2017). How Moroccan institutional investors view dividend policy. Managerial Finance, $43(12), 1332-1347$. https://doi.org/10.1108/MF-06-2017-0215

Baker, H.K., Kapoor, S., \& Jabboury, I. (2018). Institutional perspectives of dividend policy in India. Qualitative Research in Financial Markets, 10(3), 324-342. https://doi.org/10.1108/QRFM-07-2017-0067

Baker, H.K, Kilincarslan, E., \& Arsal, A. (2017). Dividend policy in Turkey: Survey evidence from Borsa Istanbul Firms. Global finance journal, 35(2), 43-57. https://doi.org/10.1016/j.gfj.2017.04.002

Baker, H.K, Powell, G., \& Veit, E. (2002). Revisiting managerial perspectives on dividend policy. Journal of Economics and Finance, 26(3), 267-283. https://doi.org/10.1007/BF02759711

Basse, T. (2019). The impact of the financial crisis on the dividend policy of the European insurance industry: additional empirical evidence. Zeitschrift für die gesamte Versicherungswissenschaft, 108(1), 3-17. https://doi.org/10.1007/s12297-019-00429-w 


\section{ENTREPRENEURSHIP AND SUSTAINABILITY ISSUES}

ISSN 2345-0282 (online) http://jssidoi.org/jesi/ 2020 Volume 8 Number 2 (December) http://doi.org/10.9770/jesi.2020.8.2(1)

Bhattacharya, S. (1979). Imperfect information, dividend policy, and the bird in the hand fallacy. The Bell Journal of Economics, 5(1), 259-70. https://doi.org/10.2307/3003330

Benartzi, S., Michaely, R., \& Thaler, R. (1997). Do changes in dividends signal the future or the past?. Journal of Finance, 52(3), 10071034. https://doi.org/10.1111/j.1540-6261.1997.tb02723.x

Berezinets, I.V., Bulatova, L.A., Ilina, Y.B., \& Smirnov, M.V. (2019). Reactions of emerging stock markets to dividend announcements during economic growth: evidence from India and Russia. Eurasian Economics Review, 9(1), 71-89. https://doi.org/10.1007/s40822-018$\underline{0111-7}$

Booth, L., Aivazian, V., Demirguc-Kunt, A. \& Maksimovic, V. (2001). Capital structures in developing countries. The Journal of Finance, 56, 87-130. https://doi.org/10.1111/0022-1082.00320

Borde, S., Byrd, A., \& Atkinson, S. (1999). Stock price reaction to dividend increases in the hotel and restaurant sector. Journal of Hospitality and Tourism Research, 23(1), 40-52. https://doi.org/10.1177\%2F109634809902300104

Braggion, F. \& Moore, L. (2011). Dividend policies in an unregulated market: The London Stock Exchange. Review of Financial Studies, 24, 2935-2973. Retrieved from https://econpapers.repec.org/RePEc:oup:rfinst:v:24:y:2011:i:9:p:2935-2973

Brav, A., Graham, J., Harvey, C., \& Michaely, R. (2005). Pay-out policy in the 21st century. Journal of Financial Economics, 77(3), 483527. https://doi.org/10.1016/j.jfineco.2004.07.004

Chaudhary, G.M., Hashmi, S.H., \& Younis, A. (2016). Does Dividend Announcement Generate Market Signal? Evidence from Pakistan. International Journal of Economics and Financial Issues, 6(1), 65-72. Retrieved from https://www.semanticscholar.org/paper/DoesDividend-Announcement-Generate-Market-Signal-Chaudhary-Hashmi/5081688b602942ade85e9be8c73448889be5f7a0a

Dasilas, A. (2009). Stock market reaction to dividend announcements: Evidence from the Greek Stock Market. https://dx.doi.org/10.2139/ssrn.981885

DeAngelo, H., DeAngelo, L., \& Skinner, D. (1996). Reversal of fortune: dividend signalling and the disappearance of sustained earnings growth. Journal of Financial Economics, 40, 341-371. https://doi.org/10.1016/0304-405X(95)00850-E

Denis, D., \& Osobov, I. (2008). Why do firms pay dividends? International evidence on the determinants of dividend policy. Journal of Financial Economics, 89, 62-82. https://doi.org/10.1016/j.jfineco.2007.06.006

Eades, K., Hess, P., \& Kim, E. (1985). Market rationality and dividend announcements. Journal of Financial Economics, 14, 581-604. https://doi.org/10.1016/0304-405X(85)90027-3

Ghafoor, A., Khan, M.A., Shah, S.A., \& Khan, H.H. (2014). Inflation and dividend behavior of Pakistani firms: An empirical investigation using ARDL. International Journal of Business and Management, 9(9), 86-95. https://doi.org/10.5539/ijbm.v9n9p86

Gonedes, N. (1978), Corporate signalling, external accounting, and capital market equilibrium: Evidence on dividends, income, and extraordinary items. Journal of Accounting Research, 16, 26-79. https://doi.org/10.2307/2490411

Gordon, M. (1962). The investment, financing, and valuation of the corporation. R. D. Irwin.

Grullon, G., Michaely, R., Benartzi, S., \& Thaler, R. (2005). Dividend changes do not signal changes in future profitability. Journal of Business, 78, 1659-1682. https://doi.org/10.2139/ssrn.431762

Grullon, G., Michaely, R. \& Swaminatham, B. (2002). Are dividend changes a sign of firm maturity?. Journal of Business, 75(3), 387-424. https://doi.org/10.1086/339889

Gupta, M., \& Aggrawal, N. (2018). Signaling Effect of Shifts in Dividend Policy: Evidence from Indian Capital Markets. Business Perspectives and Research, 6(2), 142-153. https://doi.org/10.1177\%2F2278533718764505

Ham, C., Kaplan, Z., \& Leary, M.T. (2019), Do Dividends Convey Information About Future Earnings? http://dx.doi.org/10.2139/ssrn.3176055

Harada, K., \& Nguyen, P. (2005). Dividend change context and signaling efficiency in Japan. Pacific-Basin Finance Journal, 13, 504-522. https://doi.org/10.1016/j.pacfin.2005.01.001 


\section{ENTREPRENEURSHIP AND SUSTAINABILITY ISSUES}

ISSN 2345-0282 (online) http://jssidoi.org/jesi/ 2020 Volume 8 Number 2 (December) http://doi.org/10.9770/jesi.2020.8.2(1)

Healy, P., \& Palepu, K. (1988). Earnings information conveyed by dividend initiation and omissions. Journal of Financial Economics, 21(2), 149-75. https://doi.org/10.1016/0304-405X(88)90059-1

Henderson, B. D. (1979). Henderson on corporate strategy. Cambridge, Mass.: Abt Books.

Impson, M. (1997). Market reaction to dividend-decrease announcements: Public utilities vs. unregulated industrial firms. The Journal of Financial Research, 20(3), 407-22. https://doi.org/10.1111/j.1475-6803.1997.tb00257.x

Jensen, M. (1986), Agency costs of free cash flow, corporate finance, and takeovers. American Economic Review, 76, 323-329. https://www.jstor.org/stable/1818789

Jensen, M. \& Meckling, W. (1976). Theory of the firm: managerial behaviour, agency costs and ownership structure. Journal of Financial Economics, 3(2), 305-360. https://doi.org/10.1016/0304-405X(76)90026-X

John, K. \& Williams, J. (1985). Dividends, dilution, and taxes: A signalling equilibrium. The Journal of Finance, 40(4), 1053-1070. https://www.jstor.org/stable/2328394

Kadığlu, E., \& Öcal, N. (2016). Dividend Changes and Future Profitability: Evidence from the Turkish Stock Market. International Journal of Economics and Finance, 8(3), 196-205. https://doi.org/10.5539/ijef.v8n3p196

Kaplan, Z., \& Perez Cavazos, G. (2019). Dividend Signaling With Excess Cash. http://dx.doi.org/10.2139/ssrn.3393065

Khanal, A.R., \& Mishra, A.K. (2017). Stock price reactions to stock dividend announcements: A case from a sluggish economic period. North American Journal of Economics and Finance, 42, 338-345. https://doi.org/10.1016/j.najef.2017.08.002

Liaqat, A., Saima, B. \& Saqib, A. (2019). Managerial perspective regarding signaling effects of dividend policy: a case study of Pakistan stock exchange. City University Research Journal, 9(1), 98-111. Retrieved from http://www.cusit.edu.pk/curj/Journals/Journal/Jan\%202019/08\%20Article.pdf

Liu, C., \& Chen, A. (2015). Do firms use dividend changes to signal future profitability? A simultaneous equation analysis. International Review of Financial Analysis, 37, 194-207. https://doi.org/10.1016/j.irfa.2014.12.001

Lotfi, T. (2018). Dividend and Stock Repurchase Announcement in Tunisia: A Signaling Approach. Global Journal of Management and Business Research, 18(1), 33-52. https://journalofbusiness.org/index.php/GJMBR/article/view/2419

Lukose, J., \& Rao, S. (2010). Dividend changes and profitability: an empirical study of Indian manufacturing firms. The IUP Journal of Applied Finance, 6(1), 1-25. https://www.questia.com/library/journal/1P3-1965392461/dividend-changes-and-profitability-an-empirical$\underline{\text { study }}$

Lys, T., Naughton, J., \& Wang, C. (2015). Signaling through corporate accountability reporting. Journal of Accounting and Economics, 60(1), 56-72. https://doi.org/10.1016/j.jacceco.2015.03.001

Nam, H.J. (2018). The dividend payout policy and R\&D for loss firms: evidence from South Korea. Asia-Pacific Journal of Accounting \& Economics, 26(1-2), 172-183. https://doi.org/10.1080/16081625.2019.1546564

Nissim, D., \& A. Ziv. (2001). Dividend changes and future profitability. Journal of Finance, 56, 2111-2133. https://doi.org/10.1111/0022$\underline{1082.00400}$

Miller, M.H., \& F. Modigliani. (1961). Dividend policy, growth, and the valuation of shares. Journal of Business, 34, 411-433. http://dx.doi.org/10.1086/294442

Miller, M. \& Rock, K. (1985). Dividend policy under asymmetric information. The Journal of Finance, 40(4), 1031-1051. https://doi.org/10.1111/j.1540-6261.1985.tb02362.x

Penman, S. (1983). The predictive content of earnings forecasts and dividends. Journal of Finance, 38, 1181-1199. https://doi.org/10.1111/j.1540-6261.1983.tb02290.x

Rabbani, N. (2017). The Announcement Effect of Cash Dividend Changes on Share Prices: Evidence from Dhaka Stock Exchange. Review of Pacific Basin Financial Markets and Policies, 20(4), 1750025(1-19). https://doi.org/10.1142/S0219091517500254 


\section{ENTREPRENEURSHIP AND SUSTAINABILITY ISSUES}

ISSN 2345-0282 (online) http://jssidoi.org/jesi/ 2020 Volume 8 Number 2 (December) http://doi.org/10.9770/jesi.2020.8.2(1)

Smith, D.D., \& Pennathur, A.K. (2017). Signaling Versus Free Cash Flow Theory: What Does Earnings Management Reveal About Dividend Initiation?. Journal of Accounting, Auditing \& Finance, 34(2), 284-308. https://doi.org/10.1177\%2F0148558X17724051

Smith M. (2002). Derrick's Ice-Cream Company: applying the BCG matrix in customer profitability analysis. Accounting Education 11 (4), 365-375. ,https://doi.org/10.1080/0963928021000031457

Tao, Q., Nan, R., \& Li, H. (2016), Information content of unexpected dividends under a semi-mandatory dividend policy: An empirical study of China. The North American Journal of Economics and Finance, 37, 297-318. https://doi.org/10.1016/j.najef.2016.05.001

Tran, Q.T., \& Mai, Y.D. (2015). Stock Market Reaction to Dividend Announcements from a Special Institutional Environment of Vietnamese Stock Market. International Journal of Economics and Finance, 7(9), 50-58. https://doi.org/10.5539/ijef.v7n9p50

Travlos, N., Trigeorgis, L., \& Vafeas, N. (2001). Shareholder wealth effects of dividend policy changes in an emerging stock market: the case of Cyprus, Multinational Finance Journal, 5(2), 87-112. Retrieved from http://www.mfsociety.org/modules/modDashboard/uploadFiles/journals/googleScholar/696.html

Watts, R. (1973). The information content of dividends. Journal of Business, 46, 191-211. http://dx.doi.org/10.1086/295525

Widiatama Yulizar, Abdul Hamid Aceng, Martono (2018), International Journal of Economics and Financial Issues, 8(4), $222-226$. https://www.econjournals.com/index.php/ijefi/article/view/6652

Zhao, R.L. (2016). Dividend Signaling: What Can We Learn from Corporate Bond Responses?. Journal of Internet Banking and Commerce, 21(1), 1-15. http://www.icommercecentral.com/open-access/dividend-signaling-what-can-we-learn-from-corporate-bondresponses.php?aid $=70481$

Alireza AGHAEE Shahrbabaki is a Ph.D student at Bocconi University, Department of Finance, Bocconi School of Management, Milan, Italy

ORCID ID: 0000-0001-5670-9092

Saeed SAKKAKI is an MBA graduate from Graduate School of Management and Economics, Sharif University of Technology, Tehran, Iran

ORCID ID: 0000-0001-5476-6077

Peyman PARSA is an MBA graduate from Department of Industrial Enginerring, K.N. Toosi University ofTechnology, Tehran, Iran ORCID ID: 0000-0002-3064-8663

Mohammad Saeed HEIDARY is a Ph.D student at Department of finance, Faculty of Management and Accounting, Allameh Tabataba'i University, Tehran, Iran.

ORCID ID: 0000-0003-2383-4174

Vahid YOUSEFIPOUR is MBA graduate from Graduate School of Management and Economics, Sharif University of Technology, Tehran, Iran

ORCID ID: 0000-0002-6841-5646

Make your research more visible, join the Twitter account of ENTREPRENEURSHIP AND SUSTAINABILITY ISSUES: @Entrepr69728810

Copyright (C) 2020 by author(s) and VsI Entrepreneurship and Sustainability Center

This work is licensed under the Creative Commons Attribution International License (CC BY).

http://creativecommons.org/licenses/by/4.0/

(c) (i) Open Access 